\title{
メキシコ湾流の気候への長期的影響を解明!
}

\section{見延 庄士郎}

今回、北海道大学大学院の見延庄士郎教授らのグループは、衛星から得られた詳細な観測 データと大気大循環シミュレーションを使って、メキシコ湾流が長期にわたる大気圧や風の 収束・発散、降水量、さらには対流圏の上層にまで影響を及ぼしていることを世界で初めて 発見した。詳細はNature 3 月 13 日号で発表され、その 3D 画像が表紙を飾った ${ }^{1}$ 。見延 教授に研究の成果や意義などについて聞いた。

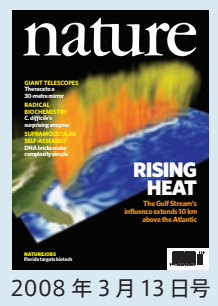

\section{暖流の膨大な熱が高度 $10 \mathrm{~km}$ まで影響を及ぼす}

Nature Digest — 今回の成果のポイントを教えてください。 見延一メキシコ湾流（以下、湾流）が比較的短期間の気象 に及ぼす影響については、以前からもよく知られていました。 しかし、長期間にわたる気候への影響やそのメカニズムは、 正確にはとらえられていなかったのです。今回我々は、湾流 の放出する熱が、表層から高度 $10 \mathrm{~km}$ に及ぶ対流圏上層に 至るまで、気候を構成するさまざまな要素に影響を与えてい ることを世界で初めて発見しました。

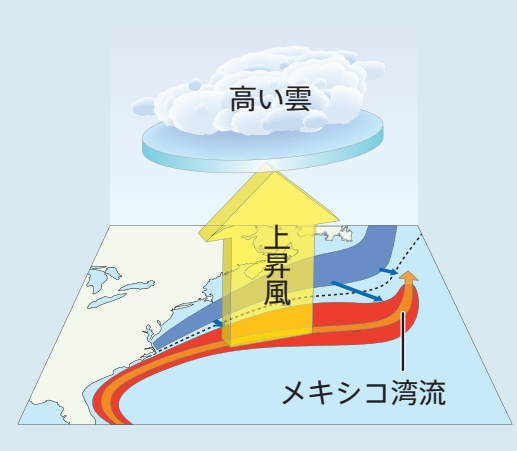

図 1 メキシコ湾流に対する大気応 答。海洋表面水温の前線（黒波線） の沖側、メキシコ湾流の直上で相対的 に低い大気圧が生じ、表面風の収束 と降水の強化（赤）が起こる。一方、 前線の岸側では、相対的に高い大気 圧に伴う風の発散が生じる(青)。収 束と発散は、海洋表面水温の前線を横 切る風によって生じている (青矢印)。 風の収束の上空では、対流圏上方に 及ぶ上昇風（黄色矢印）が生じ、そ れは上層の発散（青い楕円）と高い 雲の発生に密接に関係している。

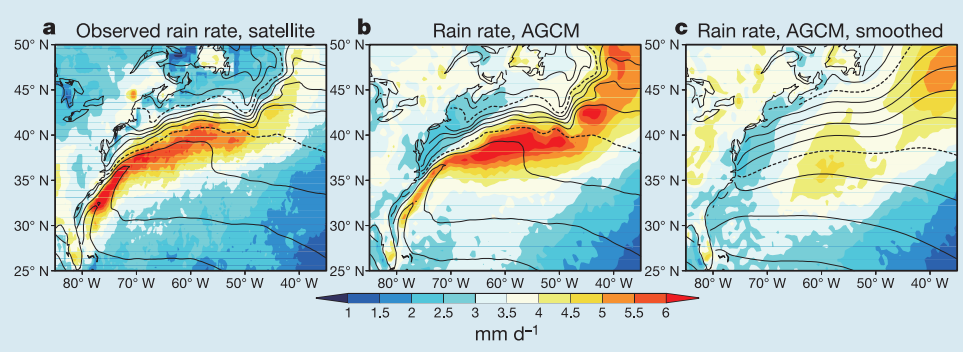

図 2 降水量の年平均値。赤いほど多く、青いほど少ない。等値線は海洋表面水温 を示し、間隔は $2^{\circ} \mathrm{Cごと、} 10^{\circ} \mathrm{C} と 20^{\circ} \mathrm{C}$ は点線。a) 衛星による降水観測、b) 観測さ れた表面水温を与えた大気大循環シミュレーション（数值モデル）、c）表面水温を平 滑化し、湾流のはたらきを消した大気大循環シミュレーション。大気は、表面水温を 平滑化すると、湾流に沿って存在した降水帯が消えることがわかる。
ND 一 湾流が気候に与えるメカニズムとは?

見延一基本となっているのは、湾流の運ぶ熱です。湾流は、 北大西洋の低緯度から中高緯度へ熱を運ぶ世界最大の暖流 です。この熱は大気を直接暖めるほか、海水を蒸発させ、そ の水蒸気を通じて大気を暖めます。この 2 つの熱放出が気 候に影響を与える根幹の仕組みです。湾流直上で蒸発が盛 んに起きます。熱によって軽くなった水蒸気を含む大気は上 昇し、上空ではしだいに冷やされて水蒸気が凝結し、雲を作 ります。このとき水蒸気は、気体から液体、固体へと相を変 えることで熱を周囲に放出します。この凝結熱によって周囲 の大気は暖められ、軽くなってさらに上昇気流を生み出します （図 1)。一方、その根元の海表面付近では、風が流れ込む、 つまり風が収束した形になり、上昇気流の源となります。ヨー ロッパ中期気象予報センターが提供している気象解析データ を用いて、我々が行った解析から、湾流で蒸発によっては最 大 $290 \mathrm{~W} / \mathrm{m}^{2}$ の熱量が放出されていることがわかりました。 これは $10 \mathrm{~m}^{2}$ あたり 1 台のカセットコンロが火を燃やしてい るのと同じ計算になります。これほど膨大な熱量が湾流によっ て放出されているのです。

ND 一 なぜ、こうした発見が可能になったのですか？

見延—1つには衛星による詳細なデータが 1999 年以降、 蓄積されたためです。また 2001 年には高解像度の気象解 析が、2002 年には地球シミュレータの運用が始まり、高解 像度の解析と数值計算が可能になりました ${ }^{2}$ 。それまでは、 数值モデルの解像度はせいぜい $2 \sim 2.5$ 度程度だったので す。それが地球シミュレータを駆使することによって、計算量 では 10 倍以上の 0.5 度という解像度を得られるようになり ました。こうした精度の高い観測值と解像度の高い計算結果 によって、海洋が大気におよぼす影響と大気の自由な運動と を区別することが可能になったのです。

ND 一 対流圏上層にはどのように影響しているのでしょう?

見延—従来、湾流などの直接的な影響は大気境界層とよば れる高度 $1 \mathrm{~km}$ 以下の場所に限られ、なかでも特に $100 \mathrm{~m}$ 以下の接地境界面で顕著であると提案されていました ${ }^{3}$ 。今 回我々は、 4 年以上の観測·解析データを解析することで、 


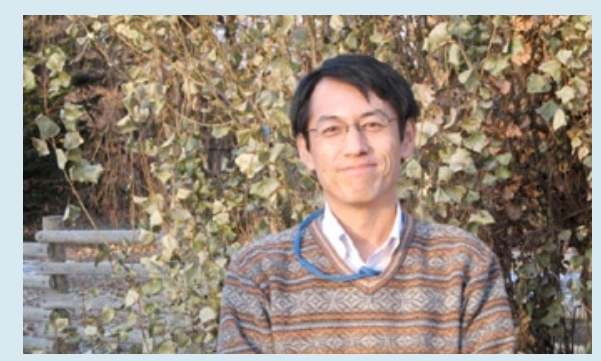

見延庄士郎（みのべ・しょうしろう）/北海道大学北 海道大学大学院理学研究科自然史科学専攻地球惑星夕゙ イナミクス講座教授。博士 (理学)。1962 年、北海道 生まれ。1985 年、北海道大学理学部地球物理学科卒 業。1989 年、北海道大学大学院理学研究科博士課程 中退。1989 年、北海道大学大学院理学研究科助手、 1997 年、同大助教授を経て、2005 年より現職。

海洋と大気の相互作用に興味をもち、大気・海洋にお ける 10 年 100 年スケール変動や、熱帯太平洋にお ける大気・海洋の季節变動などの研究を行ってきた。
今回の論文は海洋と大気上層との関連性を示したこと で、2002 年以来停滞気味だった海洋がどう大気に影 響を及ぼすかという研究において大きなブレークス ルーになると期待されている。

表紙画像の説明。メキシコ湾流上の年平均の上昇風速 (赤い部分) と海表面の地衡流速の 3 次元分布。上昇風 速は赤いほど速く、地衡流速は白いほど速い。地衡流 は湾流の流れの強さを示している。上層風速は、かな り上空まで上昇気流が到達していることを示している。
上昇気流を示す上向きの風速の存在を、対流圈の最上層で ある高度 $10 \mathrm{~km}$ 付近で発見しました。湾流の熱によって蒸発 した水蒸気は、前述のメカニズムで周囲の大気を暖めて上昇 気流を作ります。これが上向きの風速の正体です。さらに、 湾流に沿った対流圏上層で雲の発生頻度が高いことも、衛 星の観測結果から見いだすことに成功しています。湾流から 生じた水蒸気が、高い雲を周囲よりも頻繁に出現させていた のです。これほど上層まで影響を与えているという結果には、 驚かされました。

\section{表面風速の解明と狭い降水帯の発見}

ND — 表層付近では、どんなことがわかりましか?

見延一例えば、湾流の熱による湾流付近の表面風への影 響がみられます。これまで、なぜ湾流の上で風の収束が起き、 湾流よりも大陸側で風の発散が起きるのか、理由は不明でし た。その理由を知るには、衛星解析では得られない情報を 得る必要があったのです。我々は衛星観測では得られない海 面気圧に注目し、気象解析データを調べました。すると、海 面気圧の微妙なでこぼこが、観測で得られている風の収束 . 発散ととてもよく一致したのです。これは先ほどの湾流の熱 を基軸にしたメカニズムで説明可能です。つまり湾流直上で 大気が暖められて空気が軽くなって，その結果周囲よりも気 圧が少し下がるために、そこに風が流れ込んで、風の収束 が起きていたのです。一方湾流よりも沿岸に近い部分では、 それほど暖められないために、相対的に高気圧性となり、風 は発散します。

ND 一 当然、降水量とも関連しますよね?

見延一ええ。海面の風の収束によく対応する、湾流ととも に蛇行する狭い降水帯の存在を突き止めました。これは湾 流の熱が海水の蒸発を促し、雲を発生させ、雨を降らせる ためです。逆に、風が発散している湾流よりも沿岸に近い 場所では、降水量は少なくなっていました。湾流からの熱 放出は、強く降水量と関係しているのです。この関係は、地 球シミュレータでの「大気大循環シミュレーション (AFES: Atmospheric general circulation model For the Earth Simulator)」という数值モデルを使って湾流自体を なかったものにすることで証明できました。大気は、海表面の 温度変化を通じて、そこに湾流が流れているということをいわ ば感じているといえます。そこで我々は、観測值から得られた
海表面温度そのままの場合と、海表面温度を滑らかにして湾 流の存在を大気から見えないようにした場合のシミュレーショ ンを行ったのです。すると、湾流を見えなくした場合は、湾流 に沿って存在した降水帯が消えることがわかりました。つまり、 湾流の運ぶ熱とその大気への放出がなければ、湾流上の降水 帯も存在しないのです（図 2)。結局、湾流の直上で，表面風 の収束，対流圈上層に到る上昇気流，そして降水の帯が生じ ており，これらはすべて湾流からの熱放出によっているのです。

\section{地球温暖化によるメキシコ湾流への影響}

ND 一 湾流の世界の気候への影響はどうでしょう?

見延一対流圏上層に影響が出るとなると、湾流の付近にと どまらずより遠方への影響も考えられます。「線形モデル」と よばれる、原因と結果を結びつけやすい数值モデルで計算す ると、湾流からの熱放出が地球の自転に伴う大気の波として 水平伝播し、ヨーロッパ付近にまで影響を与えているという 結果が得られました。ただし、実際の大気では、一般風など のほかの気候要素との相互作用も重要で、線形モデルで求め た結果と同じ伝播をするとは必ずしもいえません。現状では、 湾流の影響を示唆したというものです。

ND 一 地球温暖化が進むと、どのような影響が出ますか?

見延一IPPC 第 4 次報告書では、温暖化によって大西洋の 熱循環が弱まることが指摘されています。湾流はこの熱循環 と関係しているため，湾流が弱くなる、あるいは南北に移動 するという影響が出る可能性があります。その場合、我々の 研究結果は、湾流の周囲の降水量分布などに直接的な影響 が出ることがまず確実であり，さらに大気の波を通じて遠方 にも影響する可能性を示しています。

ND 一 今後の課題を教えてください。

見延—湾流についてさらに研究を深めていく予定ですが、 もう1つには、同じ研究手法を使って黒潮についても詳しく 解析したいですね。黒潮は湾流と並ぶ北半球最大の暖流であ り、海洋と大気の相互作用に興味がありますから。

ND 一 ありがとうございました。

\section{聞き手は坂元志歩（サイエンスライター）}

1. Minobe S. et al. Nature, 452, 206-209(2008)

2. Enomoto, T., etal. in HighResolutionNumerical Modeling of the Atmosphereand OceanCh. 5,77-98 (Springer, New York, 2008)

3. Chelton D. B., et al. Science 303, 978-983 (2004) 